\title{
Otolith microstructural and microchemical changes associated with settlement in the diadromous fish Galaxias maculatus
}

\author{
Robin Hale $^{1,2, *}$, Stephen E. Swearer ${ }^{2}$ \\ ${ }^{1}$ School of Social and Environmental Enquiry, 221 Bouverie Street, University of Melbourne, Victoria 3010, Australia \\ ${ }^{2}$ Department of Zoology, University of Melbourne, Victoria 3010, Australia
}

\begin{abstract}
The presence of a settlement mark in the otoliths of the common galaxid Galaxias maculatus was validated by examining the relationship between changes in otolith microstructure and otolith microchemistry. Two methods were used to examine the microchemistry of otoliths: (1) laserablation multi-collector inductively-coupled plasma mass spectrometry (LA-MC-ICPMS) to examine changes in $\mathrm{Sr}$ isotope ratios, and (2) laser-ablation inductively-coupled-plasma mass spectrometry (LA-ICPMS) to examine changes in $\mathrm{Ba} / \mathrm{Ca}$ and $\mathrm{Sr} / \mathrm{Ca}$. Both analytical techniques detected changes in otolith microchemistry consistent with movement from oceans into rivers (settlement). There was a strong correlation between the timing of settlement as indicated by otolith microstructure and both Sr-based methods; however, $\mathrm{Ba} / \mathrm{Ca}$ was a less reliable marker of settlement for this species. These results support the use of this settlement mark for further otolith based studies of age, growth and the reconstruction of settlement histories in G. maculatus and demonstrate the potential utility of otolith microchemistry as a method for validating settlement marks in other diadromous fish.
\end{abstract}

KEY WORDS: Settlement mark · Otolith $\cdot$ Diadromous $\cdot$ Galaxid

Resale or republication not permitted without written consent of the publisher

\section{INTRODUCTION}

For species with highly dispersive offspring, recruitment is a key process that acts to regulate the number of individuals within a population (e.g. Roughgarden et al. 1988, Jones 1990). A common observation in aquatic systems is that recruitment is highly variable; however, limited progress has been made in identifying the sources of this variability (Chambers \& Trippel 1997). Historically, examining patterns of recruitment has involved timeconsuming and logistically difficult visual censuses of dispersing fish; however, the discovery that growth rings in fish otoliths are deposited daily (Pannella 1971) opened up the possibility of otolith-based reconstructions of recruitment (Wilson \& McCormick 1997).

Otoliths are calcium carbonate structures in the inner ear of fish that assist with balance and sound perception (Fay 1984, Popper et al. 2005). During their formation, calcium carbonate and protein are deposited differentially on a daily basis (Campana \& Neilson 1985), creating thin concentric increments. These rings allow the age, as well as growth rates, of a fish to be determined because the distance between rings is proportional to somatic growth for many species (Campana \& Neilson 1985).

In addition to age and growth, otoliths can provide information about the timing of life history events such as hatching, metamorphosis, environmental stress and habitat transitions because these processes can produce an abrupt change in the continuity of incremental structures (Brothers et al. 1983, Morales-Nin 2000). These marks are especially useful in studies of settlement, as they allow patterns of movement between habitats to be reconstructed (e.g. Pitcher 1988). However, their use is dependent on accurate validation that an observed change in the microstructure of an otolith does in fact correlate with a movement between habitats.

Because the incorporation of at least some elements into otoliths is dependent on the physical and chemical properties of the surrounding environment, analysing the microchemistry of otoliths allows fish movements to be examined (e.g. Secor et al. 1995, Elsdon \& Gillanders 
2003). In particular, changes in the $\mathrm{Sr} / \mathrm{Ca}$ ratio of otoliths can be a marker of movement between marine and freshwater habitats because Sr is often 1 to 2 orders of magnitude higher in seawater relative to freshwater and readily substitutes for $\mathrm{Ca}$ in the aragonite crystal lattice during otolith formation (Campana 1999, Secor \& Rooker 2000). Therefore, otolith microchemistry may be especially useful in studies of diadromous fish.

Nevertheless, there are potential problems with using this method because it relies on a strong relationship between otolith $\mathrm{Sr} / \mathrm{Ca}$ and $\mathrm{Sr} / \mathrm{Ca}$ in ambient water, which can be confounded by correlations between $\mathrm{Sr} / \mathrm{Ca}$ and factors other than salinity, such as water temperature and fish growth and physiology (Secor \& Rooker 2000, Martin et al. 2004). Also, steep gradients in salinity within estuaries means that in some cases estuarine Sr/Ca can exceed marine values (Kraus \& Secor 2004), meaning that Sr/Ca may not be an accurate marker of movement of diadromous fish into freshwater. Therefore, 2 potential alternatives have been proposedanalysing other elements (in particular Ba, e.g. Elsdon \& Gillanders 2005) or Sr isotope ratios (e.g. Kennedy et al. 2000, Kennedy et al. 2002, Bacon et al. 2004, Woodhead et al. 2005). These methods may be more accurate than Sr/Ca because the uptake of both Ba (Bath et al. 2000, Elsdon \& Gillanders 2004) and Sr isotopes (Kennedy et al. 2000, Secor \& Rooker 2000) may be less susceptible to confounding factors other than the chemistry of ambient water. Sr isotopic ratios are also invariant in oceanic water (0.70918, Hodell et al. 1989), resulting in an unambiguous marker of marine residency. However, while these alternatives have a number of potential advantages, studies directly comparing the accuracy of these and other elemental markers are scarce (but see Campana et al. 1997, Milton \& Chenery 2005), so it is therefore crucial that markers are compared to evaluate their accuracy and utility in different applications.

As mentioned above, otolith-based studies of age, growth and settlement depend on the accurate validation of otolith check marks. While the deposition of daily growth rings has been validated for the diadromous fish Galaxias maculatus and otoliths have previously been used in ageing studies (McDowall et al. 1994), the presence of a settlement mark has not been validated, which has greatly hindered further studies of settlement. In our preliminary observations of otolith microstructure, we observed an increase in increment width towards the edge of the otolith in recently settled fish. Our study, therefore, had 2 main aims: (1) to determine whether this is in fact a mark representative of settlement by comparing the relationship between the timing of settlement as indicated by otolith microchemistry and otolith microstructure; and (2) to examine the consistency of the 3 different methods for determining movement into rivers (Ba/Ca, Sr/Ca and $\mathrm{Sr}$ isotope ratios).

\section{MATERIALS AND METHODS}

Based on size and external pigmentation, we collected larval Galaxias maculatus with a range of postsettlement ages from the Barham, Cumberland and Grey Rivers (Victoria, Australia) from November 2003 to January 2004. The study region in general, and these rivers specifically, has already been described (Koehn \& O'Connor 1990, O'Connor \& Koehn 1998, Thomson 2002). These 3 sites were selected to encapsulate variability in catchment characteristics in the study region, and by extension to examine any possible impact of such variability on either otolith microchemistry or microstructure (e.g. either may be influenced by the presence/absence of an estuary). Fish were caught using either a $5 \mathrm{~m}$ long seine net (mesh size $5 \mathrm{~mm}$ ) or standard minnow traps, and were euthanized with clove oil and preserved in $70 \%$ ethanol. Sagittal otoliths were extracted under a dissecting microscope, cleaned of adhering tissue and air-dried. Otoliths were then embedded in thermoplastic cement (Crystalbond) on glass slides and ground in the sagittal plane using fine grade sand paper and diamond lapping films to expose all rings from hatching until capture, before being sonicated in $18 \mathrm{M} \Omega$ water for $5 \mathrm{~min}$, dried in a laminar flow bench and stored in plastic bags.

Following the methodology of Woodhead et al. (2005), laser-ablation multi-collector inductively coupled mass spectrometry (LA-MC-ICPMS) was used to analyse changes in the ${ }^{87} \mathrm{Sr} /{ }^{86} \mathrm{Sr}$ ratio. The analytical system consisted of a 'Nu Plasma' MC-ICPMS (Nu Instruments), coupled to a HelEx (Laurin Technic \& Australian National University) laser ablation system. This system was constructed around a Compex 110 (Lambda Physik) excimer laser operating at $193 \mathrm{~nm}$. After ablation under pure He to minimize re-deposition of ablated material, the sample was entrained in the Ar carrier gas flow. In this study, otoliths were analysed with a rectangular slit with a laser setting of $\sim 80 \mathrm{~mJ}$ and a repetition rate of $20 \mathrm{~Hz}$, resulting in a 5 by $150 \mu \mathrm{m}$ wide pit, with the long axis orientated parallel to the growth axis. Samples were ablated continuously along the transverse axis, from edge to edge, resulting in a $150 \mu \mathrm{m}$ transect. Data were processed offline using the methodology of Woodhead et al. (2005), whereby $0.2 \mathrm{~s}$ data slices were corrected for interferences and mass bias and then displayed as time resolved output.

To analyse changes in $\mathrm{Sr} / \mathrm{Ca}$ and $\mathrm{Ba} / \mathrm{Ca}$ ratios, laser-ablation inductively-coupled mass spectrometry (LA-ICPMS) was undertaken, using the same laser ablation system as above, coupled to a Varian $810 \mathrm{MS}$ ICPMS (Varian Australia). Otoliths were first preablated along the transect to remove any surface contamination and then analysed with the same methodology as above, but with a laser energy setting of $\sim 40 \mathrm{~mJ}$ 
and a repetition rate of $5 \mathrm{~Hz}$. Samples were run in blocks of 6, with NIST (National Institute of Standards and Technology) 610 (for Sr/Ca) and 612 (for Ba/Ca) standards run before and after each block (except the third when a standard was only completed beforehand due to instrument failure). Blank subtracted counts of $\mathrm{Sr}, \mathrm{Ca}$ and $\mathrm{Ba}$ in the standards were used to develop single-point calibration equations for each block; these equations were used to convert count data to concentrations for each of the samples. Concentrations of $\mathrm{Sr}$ and $\mathrm{Ba}$ were normalized to $\mathrm{Ca}$ (the internal standard) to control for variable ablation during analysis and expressed as molar ratios (moles element/moles Ca). In total, otoliths from 26 fish were analyzed, 19 by LA-ICPMS and 7 by LA-MC-ICPMS.

After microchemical analysis, otoliths were stored in immersion oil and an image of each was captured under $400 \times$ magnification using a compound microscope (Olympus BX50) with an attached digital camera (Spot Insight). Using image analysis software (Image-Pro v. 4.5), the position of the visual change in otolith increment width the predicted settlement mark) along the ablated transect was measured, as well as the width of 5 growth rings
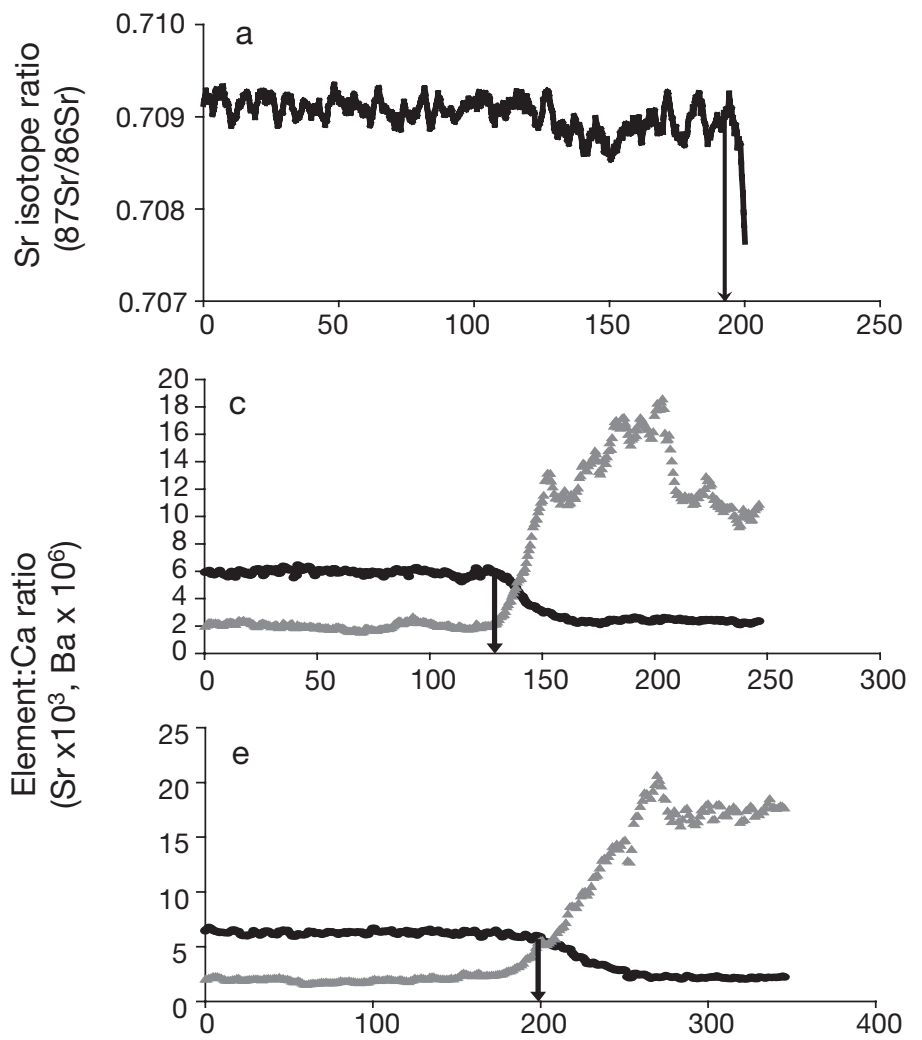

Distance from otolith core $(\mu \mathrm{m})$ prior to and 5 rings after the 'settlement mark' . Linear regression analysis was used to examine the relationship between the timing of settlement as indicated by changes in chemical profiles (i.e. rapid decreases in $\mathrm{Sr}$ and rapid increases in $\mathrm{Ba}$ ) and by changes in otolith microstructure. A split-plot ANOVA was used to determine whether the width of otolith growth rings changed after settlement (as determined by the change in otolith microchemistry). This model consisted of 2 fixed factors River (source of fish) and Position (either before or after the settlement mark) - and 1 random factor (Fish). This analysis conformed to both the common assumptions of ANOVA and those specific to split-plot designs (Quinn \& Keough 2002), so more conservative tests and transformations of the data were not undertaken.

\section{RESULTS}

Using both analysis methods, the changes detected in the chemical profile of Galaxias maculatus otoliths were consistent with movement from the ocean to freshwater (Figs. 1a,b \& 2). There was a strong positive
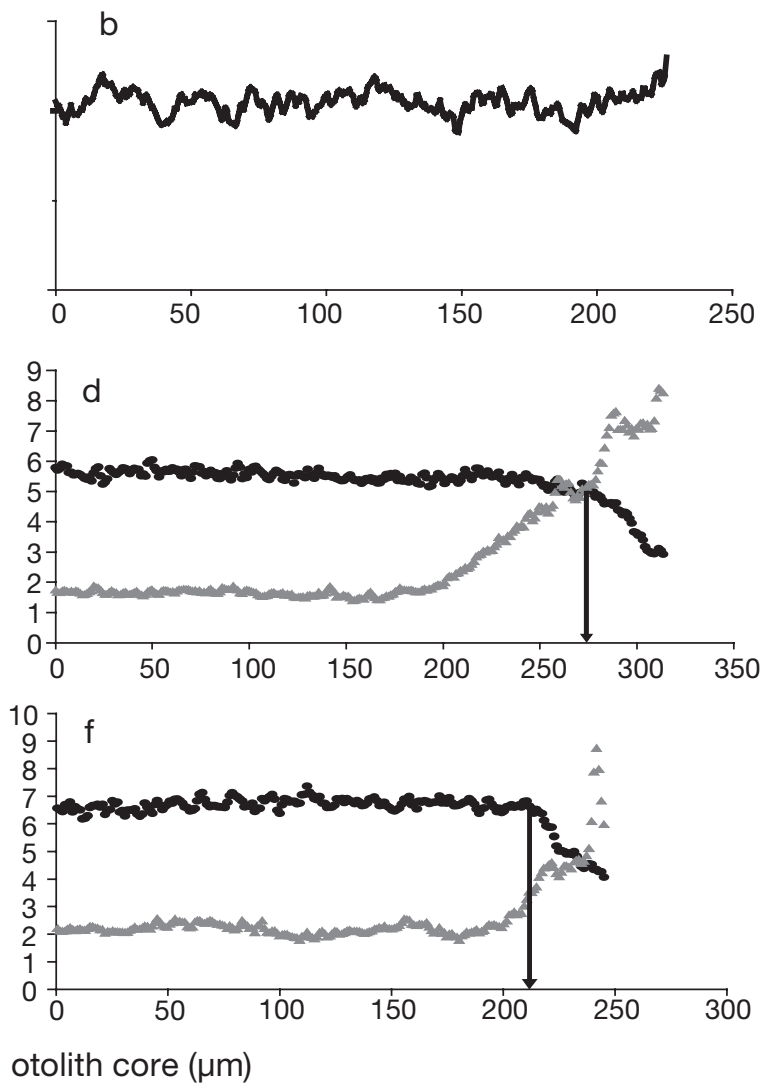

Fig. 1. Galaxias maculatus. Representative microchemical profiles from the 2 analysis methods. Panels (a) \& (b) show changes in Sr isotope ratios (analysed using LA-MC-ICPMS) for: (a) a fish that had settled $\sim 1$ wk before capture and (b) a newly settled fish.

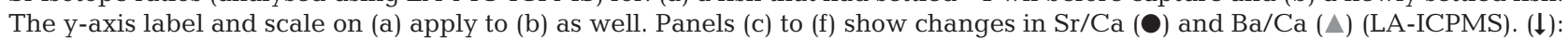
on all graphs, timing of settlement (as determined from otolith microstructure). Fish collected from Cumberland (a-c), Grey (d-e) and Barham Rivers (f) 


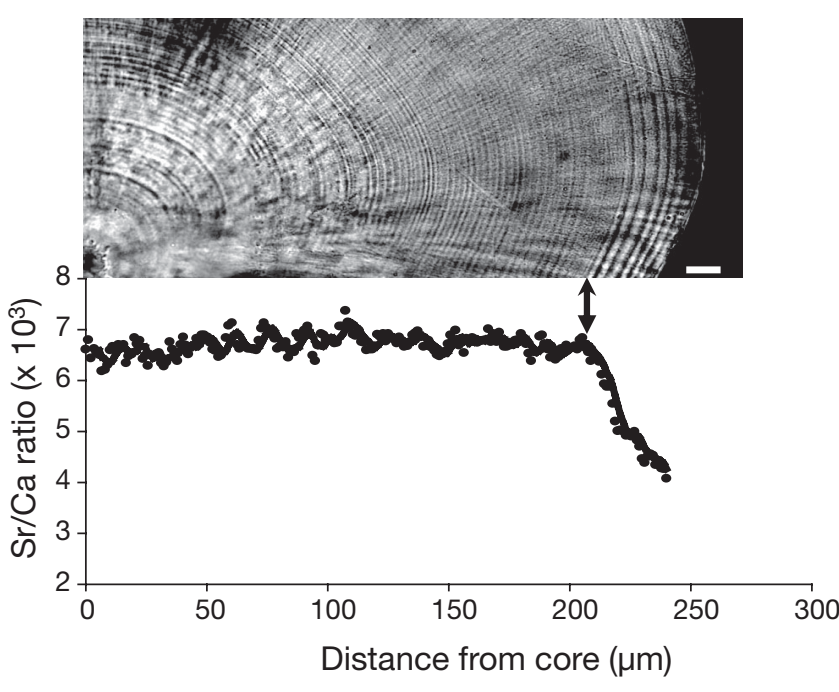

Fig. 2. Galaxias maculatus. Otolith microstructural and microchemical profiles indicating the timing of settlement $(\uparrow)$ in an otolith taken from a single fish. Note the widening of otolith rings post-settlement. The microchemical analysis was undertaken using LA-ICPMS. The white scale bar represents $15 \mu \mathrm{m}$

relationship between the timing of settlement as indicated by changes in the Sr profile (both $\mathrm{Sr} / \mathrm{Ca}$ and $\mathrm{Sr}$ isotopic ratios) and the position of the microstructural change in the otolith (Figs. $2 \& 3$ ), suggesting that the change in microstructure does in fact correspond with the movement of fish from the ocean into rivers. For both methods, the average residual of the line of best fit was less than $1.5 \mu \mathrm{m}$ (LA-MC-ICPMS = 1.31, LAICPMS $=1.46$ ). As this is less than the width of a single growth ring, it suggests that the microstructural mark provides an extremely accurate estimate of the timing of settlement.

In terms of characterizing the properties of the settlement mark, it appears as though Galaxias maculatus exhibit settlement marks similar to the zonal Type II classification of Wilson \& McCormick (1999), which feature a band of increments wider than those prior to settlement. Split-plot ANOVA revealed that otolith increments after settlement were significantly wider than those prior to settlement (mean increment width of all fish prior to settlement $=2.17 \mu \mathrm{m}$, post settlement $=3.68 \mu \mathrm{m}_{i}$ Table 1, Fig. 2). This analysis also demonstrated that this relationship was consistent between rivers, as was the width of otolith increments in general.

LA-ICPMS analysis of $\mathrm{Sr} / \mathrm{Ca}$ and $\mathrm{Ba} / \mathrm{Ca}$ as measures of the timing of settlement suggested that $\mathrm{Sr} / \mathrm{Ca}$ is a more consistent marker for this species. Linear regression analysis revealed a statistically significant positive relationship between the timing of settlement as indicated by changes in $\mathrm{Ba} / \mathrm{Ca}$ and otolith microstructure $\left(F_{1,11}=12.190, \mathrm{p}<0.01\right)$. Although this model ex- plained $53 \%$ of the variability in the relationship, the mean residual of the line of best fit was $29 \mu \mathrm{m}$ (range 0 to $85 \mu \mathrm{m}$ ) in comparison with $\leq 1.5 \mu \mathrm{m}$ for both Sr-based methods. Each of the 3 rivers provided examples of good agreement between the timing of settlement as indicated by otolith microstructure and both $\mathrm{Sr} / \mathrm{Ca}$ and $\mathrm{Ba} / \mathrm{Ca}$ (e.g. Fig. 1c), as well as examples where this was not the case with significantly more variability in the both the timing and magnitude of peaks in $\mathrm{Ba} / \mathrm{Ca}$. Most often the concentration of $\mathrm{Ba} / \mathrm{Ca}$ in the otolith increased before the concentration of $\mathrm{Sr}$ (e.g. Fig. 1d-f).

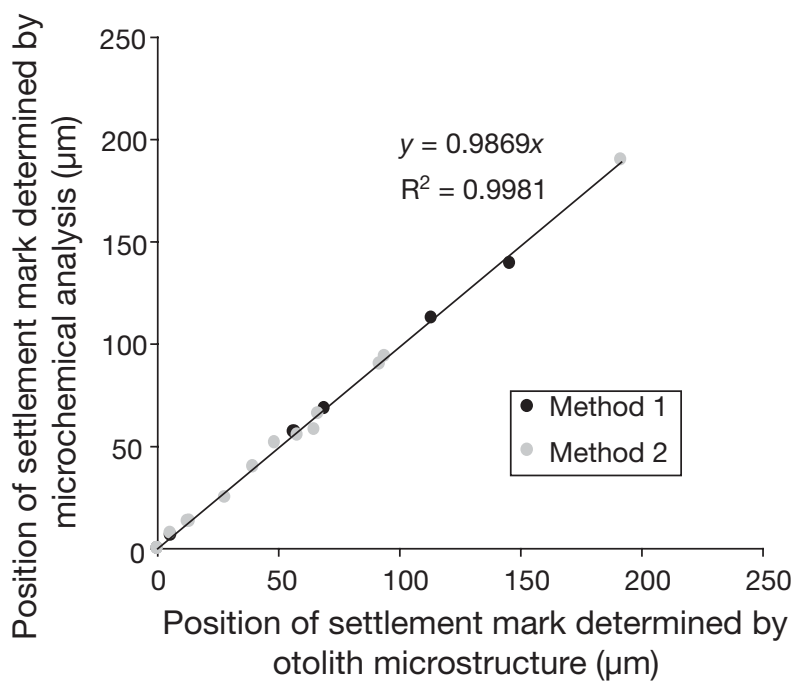

Fig. 3. Galaxias maculatus. Position of settlement mark in regards to otolith microstructural change and chemical profile. Method 1: LA-MC-ICPMS, Method 2: LA-ICPMS. Regression equation is for the line of best fit using both methods. On both axes, 0 represents the edge of the otolith

Table 1. Galaxias maculatus. Split-plot ANOVA in the width of otolith growth rings (dependent variable). Both River and Position ( 2 levels: before and after settlement mark) were treated as fixed factors

\begin{tabular}{|c|c|c|c|c|c|}
\hline & $\mathrm{df}$ & $\begin{array}{c}\text { Denomi- } \\
\text { nator MS } \\
\text { for } F \text {-ratio }{ }^{\text {a }}\end{array}$ & MS & $F$ & $\mathrm{p}$ \\
\hline \multicolumn{6}{|l|}{ Between subjects } \\
\hline 1. River & 2 & 2 & 1.248 & 1.906 & 0.188 \\
\hline 2. Fish (River) & 13 & & 0.655 & & \\
\hline \multicolumn{6}{|l|}{ Within subjects } \\
\hline 3. Position & 1 & 5 & 13.353 & 119.273 & $<0.001$ \\
\hline 4. Position $\times$ River & 2 & 5 & 0.116 & 1.032 & 0.384 \\
\hline 5. Position $\times$ & 13 & & 0.112 & & \\
\hline \multicolumn{6}{|c|}{ Fish (River) + Error } \\
\hline $\begin{array}{l}{ }^{\mathrm{a} E n t r i e s ~ i n ~ t h i s ~ c o ~} \\
\text { the left column }\end{array}$ & & refer to th & the effec & cts numb & sered in \\
\hline
\end{tabular}




\section{DISCUSSION}

Both analysis methods involving $\mathrm{Sr}$ demonstrated that the perceived change in otolith microstructure does in fact correlate with fish moving from oceans into rivers. It appears as though the timing of settlement can be determined with a high degree of accuracy using otolith microstructure because the mean residual of the line relating the position of settlement as determined by analyses of otolith $\mathrm{Sr}$ (both $\mathrm{Sr} / \mathrm{Ca}$ and $\mathrm{Sr}$ isotopes) and microstructure was $<1.5 \mu \mathrm{m}$.

It is interesting that Galaxias maculatus appear to have a settlement mark similar to the Type II classification of Wilson \& McCormick (1999). The majority of reef fish species exhibit a rapid decrease in otolith increment width at settlement (Type I, Wilson \& McCormick 1999, Raventos \& Macpherson 2001), possibly due to the physiological metamorphosis many fish undergo, which can involve a period of nonfeeding and hence reduced growth. After settlement, G. maculatus undergo a decrease in standard length (McDowall \& Eldon 1980); however, it appears as though their otoliths are going through a period of increased growth. This suggests that otolith growth and somatic growth may become decoupled during or shortly after settlement.

A number of researchers have discussed the potential confounding of the relationship between otolith $\mathrm{Sr} / \mathrm{Ca}$ and ambient Sr/Ca by factors such as fish growth rate and physiology and water temperature (e.g. Radtke \& Shafer 1992, Secor \& Rooker 2000). Analyses of both changes in $\mathrm{Sr}$ isotopes (e.g. Kennedy et al. 2000, Kennedy et al. 2002) and other elements (e.g. Ba/Ca, Elsdon \& Gillanders 2005) have been suggested as alternative markers of movement between marine and fresh waters. In terms of our study, changes in both $\mathrm{Sr} / \mathrm{Ca}$ and $\mathrm{Sr}$ isotopes were strongly correlated with the position of changes in otolith microstructure. Although $\mathrm{Ba} / \mathrm{Ca}$ and otolith microstructure were also correlated, this relationship was far more variable. Because otolith rings for this species are generally 2 to $3 \mu \mathrm{m}$ wide, a mean residual of $29 \mu \mathrm{m}$ from the line of best fit represents a discrepancy of up to $2 \mathrm{wk}$ in terms of estimating the timing of settlement (as indicated by otolith microstructure) using $\mathrm{Ba} / \mathrm{Ca}$ versus less than $1 \mathrm{~d}(<1.5 \mu \mathrm{m})$ using either Sr-based method.

In a number of cases, peaks in $\mathrm{Ba} / \mathrm{Ca}$ occurred earlier than peaks in $\mathrm{Sr} / \mathrm{Ca}$, which could be interpreted as evidence that $\mathrm{Ba} / \mathrm{Ca}$ may be the actual marker for the transition into an estuary from the ocean, as there is a greater bioavailability of $\mathrm{Ba}$ in fresh water relative to salt water (Elsdon \& Gillanders 2005, and references therein), and that the Sr-based methods may provide a marker of movement into completely fresh water.
However, for a number of reasons we consider this to be unlikely. First, larval galaxids develop pigmentation shortly after entering freshwater (McDowall \& Eldon 1980), and a number of fish were collected close to the mouths of rivers and were completely unpigmented, indicating that these fish had spent little time in the estuary prior to capture. Secondly, the variability in $\mathrm{Ba}$ was consistent across samples from all 3 sites, one of which (Grey River) has very infrequent tidal penetration and is completely fresh even at the river mouth. If $\mathrm{Ba} / \mathrm{Ca}$ were a more accurate marker of movement from the ocean, we would not have expected variation in this river because there is effectively no estuary (but see Fig. 1 d,e). Therefore, Sr-based methods appear to be more accurate markers of settlement for this species in the 3 focus rivers. In future, however, elemental profiles of otoliths from competent larvae collected prior to entry into rivers would provide definitive evidence that Sr-based methods are the most accurate microchemical marker of settlement in Galaxias maculatus.

The validation of a settlement mark using otolith microchemistry has a number of important implications. In particular, this enables future research based on the use of this check mark-such as age, growth and the reconstruction of settlement-to be conducted on Galaxias maculatus, without time consuming and expensive otolith microchemistry analysis. However, our results clearly demonstrate the general value of otolith microchemistry as a tool for validating settlement marks for other diadromous fishes. Finally, our study highlights the need for further research examining the accuracy of different otolith chemical signatures as markers of habitat transition during fish life histories. Although there are clear chemical markers recorded in otoliths that are associated with transitions between marine and freshwater habitats, it remains to be tested if other transitions, such as from pelagic to benthic habitats, also result in detectable and consistent changes in otolith chemistry.

Acknowledgements. This project was supported by an Australian Research Council Discovery Grant awarded to S.E.S. and an Australian Postgraduate Award to R.H. Funding for fieldwork was provided by a grant from the Holsworth Wildlife Research Fund awarded to R.H. Additional funds from an Albert Shimmins Postgraduate Writing-Up Award and the School of Social and Environmental Enquiry to R.H. are acknowledged. We thank the following individuals for assistance collecting samples: N. Barbee, A. Hicks, J. Morrongiello, L. McNiven, S. Metcalf, D. Hale and M. Hale. Thank you to J. Woodhead for assistance with LA-MC-ICPMS analyses and D. Paul for help with preparing the otolith photograph. Constructive comments by B. Downes and 2 anonymous reviewers helped improve the manuscript. 


\section{LITERATURE CITED}

Bacon CR, Weber PK, Larsen KA, Reisenbichler R, Fitzpatrick JA, Wooden JL (2004) Migration and rearing histories of chinook salmon (Oncorhynchus tshawytscha) determined by ion microprobe $\mathrm{Sr}$ isotope and $\mathrm{Sr} / \mathrm{Ca}$ transects of otoliths. Can J Fish Aquat Sci 61:2425-2439

Bath GE, Thorrold SR, Jones CM, Campana SE, McLaren JW, Lam JWH (2000) Strontium and barium uptake in aragonitic otoliths of marine fish. Geochim Cosmochim Acta 64: 1705-1714

Brothers EB, Williams DM, Sale PF (1983) Length of larval life in twelve families of fishes at One Tree Lagoon, Great Barrier Reef, Australia. Mar Biol 76:319-324

Campana SE (1999) Chemistry and composition of fish otoliths: pathways, mechanisms and applications. Mar Ecol Prog Ser 188:263-297

Campana SE, Neilson JD (1985) Microstructure of fish otoliths. Can J Fish Aquat Sci 42:1014-1032

Campana SE, Thorrold SR, Jones CM, Gunther D and others (1997) Comparison of accuracy, precision and sensitivity in elemental assays of fish otoliths using the electron microprobe, proton-induced X-ray emission, and laser ablation inductively coupled plasma mass spectrometry. Can J Fish Aquat Sci 54:2068-2079

Chambers RC, Trippel EA (1997) Early life history and recruitment in fish populations. Chapman \& Hall, London

Elsdon TS, Gillanders BM (2003) Reconstructing migratory patterns of fish based on environmental influences on otolith chemistry. Rev Fish Biol Fish 13:219-235

Elsdon TS, Gillanders BM (2004) Fish otolith chemistry influenced by exposure to multiple environmental variables. J Exp Mar Biol Ecol 313:269-284

Elsdon TS, Gillanders BM (2005) Alternative life-history patterns of estuarine fish: barium in otoliths elucidates freshwater residency. Can J Fish Aquat Sci 62:1143-1152

Fay RR (1984) The goldfish ear codes the axis of acoustic particle motion in 3 dimensions. Science 225:951-954

Hodell DA, Mueller PA, McKenzie JA, Mead GA (1989) Strontium isotope stratigraphy and geochemistry of the late neocene ocean. Earth Planet Sci Lett 92:165-178

Jones GP (1990) The importance of recruitment to the dynamics of a coral-reef fish population. Ecology 71:1691-1698

Kennedy BP, Blum JD, Folt CL, Nislow KH (2000) Using natural strontium isotopic signatures as fish markers: methodology and application. Can J Fish Aquat Sci 57:2280-2292

Kennedy BP, Klaue A, Blum JD, Folt CL, Nislow KH (2002) Reconstructing the lives of fish using strontium isotopes in otoliths. Can J Fish Aquat Sci 59:925-929

Koehn JD, O'Connor WG (1990) Distribution of freshwater fish in the Otway Region, south-western Victoria. Proc R Soc Vic 102:29-39

Kraus RT, Secor DH (2004) Incorporation of strontium into otoliths of an estuarine fish. J Exp Mar Biol Ecol 302: 85-106

Martin GB, Thorrold SR, Jones CM (2004) Temperature and salinity effects on strontium incorporation in otoliths of lar-

Editorial responsibility: Cynthia Jones,

Norfolk, Virginia, USA val spot (Leistomus xanthurus). Can J Fish Aquat Sci 61: $34-42$

McDowall RM, Eldon GA (1980) The ecology of whitebait migrations (Galaxiidae: Galaxias sp.). Fish Res Bull 20: $1-110$

McDowall RM, Mitchell CP, Brothers EB (1994) Age at migration from the sea of juvenile Galaxias in New Zealand (Pisces: Galaxiidae). Bull Mar Sci 54:385-402

Milton DA, Chenery SR (2005) Movement patterns of barramundi, Lates calcarifer, inferred from $\mathrm{Sr}-87 / \mathrm{Sr}-86$ and $\mathrm{Sr} / \mathrm{Ca}$ ratios in otoliths indicate non-participation in spawning. Mar Ecol Prog Ser 301:279-291

Morales-Nin B (2000) Review of the growth regulation processes of otolith daily increment formation. Fish Res 46: 53-67

O'Connor WG, Koehn JD (1998) Spawning of the broadfinned Galaxias, Galaxias brevipinnis Gunther (Pisces: Galaxiidae) in coastal streams of southeastern Australia. Ecol Freshw Fish 7:95-109

Pannella G (1971) Fish otoliths: daily growth layers and periodic patterns. Science 173:1124-1127

Pitcher CR (1988) Validation of a technique for reconstructing daily patterns in the recruitment of coral reef damselfish. Coral Reefs 7:105-111

Popper AN, Ramcharitar J, Campana SE (2005) Why otoliths? Insights from inner ear physiology and fisheries biology. Mar Freshw Res 56:497-504

Quinn GP, Keough MJ (2002) Experimental design and data analysis for biologists. Cambridge University Press, Cambridge

Radtke RL, Shafer DJ (1992) Environmental sensitivity of fish otolith microchemistry. Aust J Mar Freshw Res 43: 935-951

Raventos N, Macpherson E (2001) Planktonic larval duration and settlement marks on the otoliths of Mediterranean littoral fishes. Mar Biol 138:1115-1120

Roughgarden J, Gaines S, Possingham H (1988) Recruitment dynamics in complex life cycles. Science 241:1460-1466

Secor DH, Rooker JR (2000) Is otolith strontium a useful scalar of life cycles in estuarine fishes? Fish Res 46:359-371

Secor DH, Henderson-Arzapalo A, Piccoli PM (1995) Can otolith microchemistry chart patterns of migration and habitat utilization in anadromous fishes? J Exp Mar Biol Ecol 192:15-33

Thomson JR (2002) The effects of hydrological disturbance on the densities of macroinvertebrate predators and their prey in a coastal stream. Freshw Biol 47:1333-1351

Wilson DT, McCormick MI (1997) Spatial and temporal validation of settlement-marks in the otoliths of tropical reef fishes. Mar Ecol Prog Ser 153:259-271

Wilson DT, McCormick MI (1999) Microstructure of settlement-marks in the otoliths of tropical reef fishes. Mar Biol 134:29-41

Woodhead J, Swearer S, Hergta J, Maas R (2005) In situ Srisotope analysis of carbonates by LA-MC-ICP-MC: interference corrections, high spatial resolution and an example from otolith studies. J Anal Atom Spectrom 20:22-27

Submitted: December 1, 2006; Accepted: June 18, 2007

Proofs received from author(s): January 14, 2008 